\title{
Climate change adaptation in arable land use, and impact on nitrogen load at catchment scale in northern agriculture
}

\author{
Katri Rankinen ${ }^{1 *}$, Pirjo Peltonen-Sainio ${ }^{2}$, Kirsti Granlund ${ }^{1}$, Hannu Ojanen², Mikko Laapas ${ }^{3}$, Kaija Hakala ${ }^{2}$, Kalle Sippel ${ }^{1}$, \\ Juha Helenius ${ }^{4}$ and Martin Forsius ${ }^{1}$ \\ ${ }^{1}$ Finnish Environment Institute, P.O. Box 140, Fl-00251 Helsinki, Finland \\ ${ }^{2}$ MTT Agrifood Research Finland, Plant Production Research, Fl-31600 Jokioinen, Finland, \\ ${ }^{3}$ Finnish Meteorological Institute, P.O. Box 503, Fl-00101 Helsinki, Finland \\ ${ }^{4}$ Department of Agricultural Sciences, P.O. Box 27, FI-00014 University of Helsinki, Finland \\ *e-mail: katri.rankinen@ymparisto.fi,
}

\begin{abstract}
Prolongation of the growing season due to a warming climate could represent new opportunities for northern agriculture. Climatic and biotic constraints may, however, together with increasing risk for higher nutrient loads, challenge future crop production. The objective of this study was to speculate how a range of arable land use patterns, resulting from various policy driven choices, could be introduced into a farming system, and how they would affect the risks associated with nutrient leaching. The case study area included 720 ha of arable fields in southern Finland. Climate change scenarios were calculated using averages of 19 climate models and emission scenarios B1, $\mathrm{A} 1 \mathrm{~B}$ and $\mathrm{A} 2$. Four crop choice and allocation storylines were developed according to policy objectives: increased protein self-sufficiency, increased winter cover for reducing nutrient loading, diversification, and monoculture for cereal production. Grasslands and leys were not included in any of the production scenarios. Impacts of these land uses on sediment loading and nitrogen leaching were simulated using WSFS and INCA modelling. We found that while adaptation to climate change must include consideration of crop choices, there are conflicts associated with allocations and rotations for various market and policy situations. The expected increase in nutrient loading in the simulations caused by climate change was moderate. The increase can partly be compensated for by changes in farmland use, more in the shorter term than in the longer term to mid-century. To reduce suspended sediment load in the changed climate, vegetation cover in winter was important. For nitrogen leaching, adjusting the $\mathrm{N}$ balance at parcel level was more important than vegetation cover. In the future, adaptation at cropping system level is potentially an efficient way to manage nutrient load risks.
\end{abstract}

Key words: adaptation, cereals, climate change, crop, diversity, environment, incentives, legumes, minor crops, monoculture, nitrogen leaching, policy, protein self-sufficiency, rapeseed, soil cover

\section{Introduction}

Climate change is projected to have profound effects on Finnish agriculture within the coming decades (PeltonenSainio et al. 2009a). As the short growing season is the dominant factor contributing to modest yields, high yield variability and limited availability of (mainly spring sown) crops in Finland (Peltonen-Sainio et al. 2009b, 2009c, 2011a, 2011b), prolongation of the growing season induced by climate warming could represent new opportunities for agriculture. Thermal winter will shorten more rapidly than thermal summer will lengthen, especially in southern Finland (Ruosteenoja et al. 2011). Compared with the current conditions during the winter months, warming will result in more thaw days, less frequent and shorter periods of severe frost and a rise in the extreme minimum temperatures (Laapas et al. 2012). Climatic and biotic constraints may, however, together with increasing risks for nutrient loads, challenge crop production in the future (Kallio et al. 1997, Puustinen et al. 2007, Peltonen-Sainio et al. 2009a, Hakala et al. 2011, Trnka et al. 2011). Therefore, prompt adaptation measures, including plant breeding and development of technologies and management systems, as well as policy incentives that support and/or direct farmers' decision making, are needed to enable sustainable intensification of northern agroecosystems in the future (Ministry of Agriculture and Forestry 2011, Olesen et al. 2011).

Projected prolongation of the growing season, together with elevated mean temperatures, may open up new opportunities for diversification in northern cropping systems. Currently cereal monocultures dominate the southern parts of Finland while grasslands are especially common in dairy areas in the north. Climate change requires 
adaptation and creates opportunities in land use. However, it is not the sole driver of change in farming. Changes in demand for, and prices of crop products, novel needs for crop products, such as non-food raw materials, as well as incentives and restrictions imposed by agricultural policies, will shape future rural landscapes.

Nutrient loading is a sensitive issue in agriculture. An agri-environmental subsidy programme (EEC 1992) states that water protection is one of its main objectives and has operated in Finland since 1995. The programme is the main tool within the EU Water Framework Directive (WFD) to control nutrient loads from agricultural areas. The main goals of the WFD are to achieve good ecological and chemical status for all inland and coastal surface waters by 2015 (WFD 2000). Moreover, the Finnish Government has approved a set of national Water Protection Policy Outlines to 2015 as a decision-in-principle that also defines measures needed to improve water quality. The key objective is that nutrient loads entering water bodies from agriculture should be reduced by a third by 2015 compared to their levels over the period 2001-2005, and halved over a longer timescale (The Finnish Government 2006). Policy can attempt to influence agricultural practices such as crop choice, set aside, fertilizer application rates, tillage system, and the adoption of water protection measures. More recently, the Helsinki Commission (HELCOM) negotiated the Baltic Sea Action Plan, which by 2016 aims at cutting phosphorus (P) and nitrogen (N) inputs to the Baltic Sea by $42 \%$ and $18 \%$, respectively, from the average loads of 1997-2003. Furthermore, the former Prime Minister set a national target for nutrient recycling in Finland (Baltic Sea Action Summit 2010), recognising the problem that energy and nutrients are resources that should not be wasted. Additionally, the target of the EU Nitrate Directive (EEC 1991) is to keep nitrate concentration of surface and groundwaters below a boundary level of $50 \mathrm{mg} \mathrm{l}^{-1}$.

Risks for surface and groundwater quality are seen in Finland's National Strategy for Adaptation to Climate Change (Marttila et al. 2005). For Finland, global climate change scenarios predict increases in both precipitation and mean annual temperature (Jylhä et al. 2009). The high discharge periods and floods in particular will shift towards the winter months (Veijalainen et al. 2010). Higher suspended sediment transport from fields has been recorded in mild winters than in cold ones (Rekolainen et al. 1997, Puustinen et al. 2007). Kallio et al. (1997) predicted acceleration of organic matter mineralization and increased water flow through the soil, increasing the risk of increased nitrogen losses. Thus effective water protection measures on and outside fields are needed to reduce the risk of nutrient leaching and sediment transport.

Realization of the nutrient loading risks will depend on future arable land use, including choices of crop plant species and agronomic practices. According to the Finnish agri-environmental programme (MAVI 2011) and WFD river basin plans (Mäenpää and Tolonen 2011), the suggested water protection measures include wintertime arable vegetation cover. Winter cereals and leys serve this purpose, but even cereal stubble and reduced tillage are included in the schemes. Increasing risks of loading may result in further tightening of limits set on application of fertilizers, and implementation of specific novel methods to prevent loading.

Different scenario analysis techniques can serve as links between science and policy. The principle of scenario analysis is to explore alternative future developments with the aim of evaluating strategies to respond such developments (Alcamo 2008). For example, the IPCC describes scenarios as images of the future, or alternative futures that are neither projections nor forecasts. According to Alcamo (2011), a scenario describes how the future may unfold and typically consists of a representation of an initial situation and a description of the key driving forces and changes that lead to a particular future state.

The main objective of this study was to detail how a range of arable land use patterns resulting from various policy driven choices (such as emphasis on production of feed protein, soil and water conservation, or diversification) could be implemented, and how they would affect nutrient leaching risk. We used inquiry-driven scenario analysis as a research tool for assessing the future state of the environment (Alcamo 2011) to establish mitigation measures/policies. For immediate policy relevance, the timescales were set to the near future, and to two generations ahead, and the aim was to illustrate the situation at the local scale in a catchment in southern Finland dominated by agriculture. Climate change scenarios were calculated as averages of 19 climate models and emission scenarios B1, A1B and A2 (Nakicemovic et al. 2000). We created narrative storylines for future crop production based on two potential drivers: climate change and agricultural policy. 


\section{Materials and methods}

Hydrology and climate change scenarios in the Lepsämänjoki catchment

The Lepsämänjoki catchment (214 km², 30-95 m.a.s.l.) is a sub-basin of the Vantaanjoki river basin (Fig. 1) in southern Finland. The river Vantaanjoki discharges into the Gulf of Finland outside Helsinki. The river Lepsämänjoki is divided into two branches. The main river is meandering slowly in the middle of the fields while the tributary collects waters from forested upland area with lake percentage up to $13 \%$. The mean discharge of the river Lepsämänjoki was $2.2 \mathrm{~m}^{3} \mathrm{~s}^{-1}$ in the 2000s. The average annual precipitation in the area is $650 \mathrm{~mm}$, and annual average temperature is $4^{\circ} \mathrm{C}$.
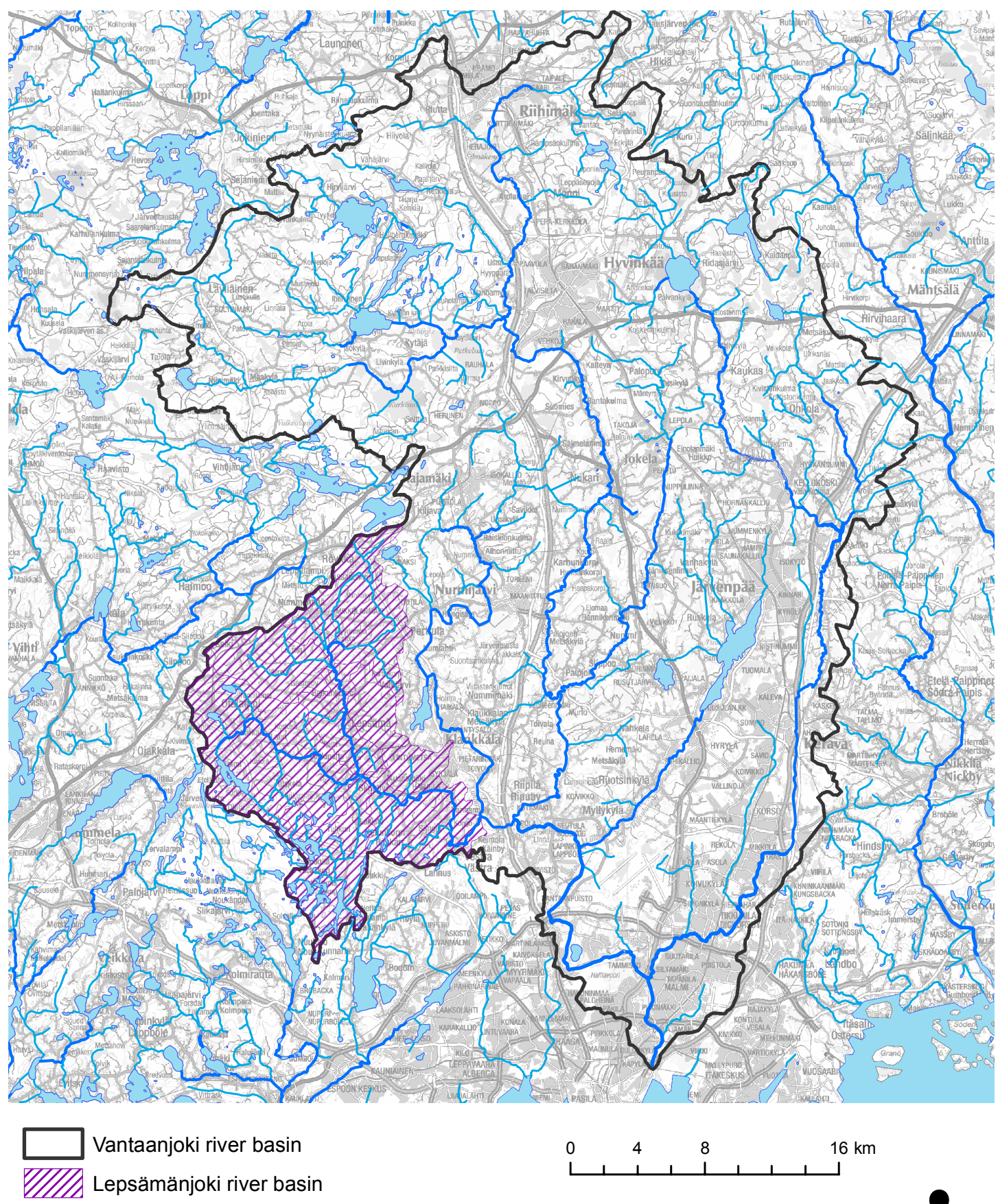

(c) Karttakeskus Oy, Lupa L4659

Fig. 1. Location of the Lepsämänjoki catchment. 
Climate change scenarios were calculated as averages of 19 climate models and emission scenarios B1, A1B and A2 (Nakicemovic et al. 2000). By interpolation from the surrounding network of meteorological stations, climate scenarios were projected for the study area for 30-year periods centred on 2025 and 2055. In 2055 the annual average temperature is predicted to increase by 2.5 degrees above the average for 1971-2000. During mid-winters the temperatures may still drop below $0{ }^{\circ} \mathrm{C}$ (Fig. 2), and some frost and snow cover may remain.

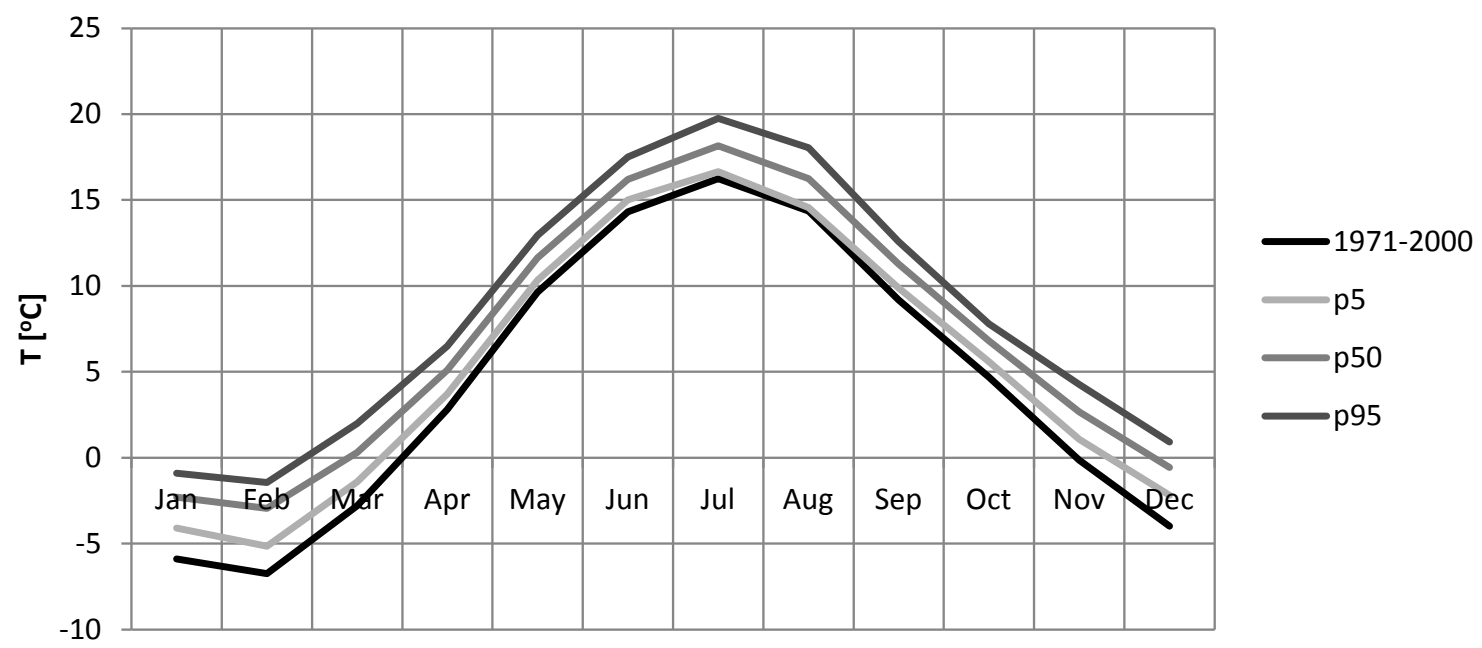

Fig. 2. Monthly mean temperatures at Lepsämänjoki catchment in the baseline period 1971-2000 and in 2055, based on interpolated projections for the study area from climate change scenarios, calculated as averages of 19 climate models and emission scenarios B1, A1B and A2 (Nakicemovic et al. 2000).

\section{Current land use and storylines for future crop production}

The Lepsämänjoki catchment is characterised by clay and rocky soils. Fields cover $25 \%$ of the total catchment area, the rest being mainly forest. Agricultural fields are located primarily on clay soils in the upper reaches of the catchment where field percentage reaches 38\% (study area). Main production line in the catchment is crop production, and the main crops are spring cereals, but at the upper reaches of the catchment there is also some cabbage cultivation (about $3 \%$ of the area). Farmers in the area are interested in different environmentally sound cultivation methods, such as catch crops, crop rotation and maintaining soil structure.

Storylines for future crop production were based on two potential drivers causing changes to cropping systems: climate change and agricultural policy. For assessing the crop plant species and land use allocations, the "worstcase" IPCC SRES (Nakicenovic et al. 2000) scenario, namely A2 (i.e., no marked international mitigation measures have been put to action or impacts have not been registered) was used. The worst-case scenario was used in order to be able to demonstrate major changes in cropping systems within the coming decades, and thereby to provide a useful test-bed for risk assessment of nutrient loading. In the case of scenario B1, which is based on the hypothesis that mitigation measures have been thoroughly and successfully put into action, the field-use storylines for A2 scenario for 2055 would approximately correspond to changes following the B1 scenario by the end of this century (2085) (Peltonen-Sainio et al. 2009a). Nevertheless, none of the SRES scenarios differ by 2025. Climate change effects on prolongation of the growing season were based on 19 climatic models that were run for 30 year periods centred on either 2025 or 2055. These data were provided by the Finnish Meteorological Institute. Thereby, according to these 19 climatic models, in the Lepsämäjoki catchment, the potential for the novel crops to be introduced into cultivation depended on prolongation of the growing season caused by climate warming. More details were provided by Peltonen-Sainio et al. (2009a) and Ruosteenoja et al. (2011). After estimating general availability of alternative crops, and their winter types when appropriate, four major production storylines were characterized based on policy drivers that may direct farmer decision-making in the future.

The storylines were generated for a study area that included 720 ha of arable land. The study did not include any considerations of current or future farm structure, in terms of farm size or land tenure. 
Storyline 1 was based on the concept that protein crop production is substantially promoted in order to increase current alarmingly low protein self-sufficiency, and thereby to decrease dependency on imported soybean (Glycine max [L.] Merr.). This is targeted according to the national strategy for improving protein self-sufficiency. In this storyline, protein crops that are well adapted to northernmost European conditions were favoured, but their rotation requirements limited expansion of their cultivation (as characterized by Peltonen-Sainio and Niemi 2012).

Storyline 2 was based on the concept that future policies heavily promote cultivation of winter crops that provide sufficient soil cover during winter to protect against erosion, sediment and nutrient transport, especially in forthcoming decades. This is in line with current environmental policy emphasis on protecting the surface waters from eutrophication in Finland (Prime Minister's Office 2011) and the current agri-environmental programme (MAVI 2011). Environmental subsidies may be directed to promote water protection as winter precipitation is projected to markedly increase at the same time as winter temperatures rise (Räisänen and Eklund 2011).

Storyline 3 postulates a business as usual situation. No substantial policy incentives are used to promote changes in crop production. This may result in domination of cereal monocultures (as currently), and in ignore the opportunities and adaptation needs in the changing climate.

Grasslands and leys were not included in any of the production scenarios. It was assumed that the present regional structure of agriculture is maintained. The study area is in an agricultural region dominated by farms specialized in crop production, while mixed farming and associated grass production are concentrated in other regions. When future field use was planned in each storyline, we took into consideration, for example, that the major crop species dominated the most appropriate fields for their cultivation. On the other hand, reed canary grass or naturally managed areas were confined to small, misshapen and/or distant fields, often nearby the main drains or watercourses, and sloping fields with clay and coarse soil types were used for autumn-sown crops.

\section{Assessment of nutrient transport risks according to the future climate scenarios and crop production storylines}

Changes in discharge and nutrient transport were modelled using the Watershed Simulation and Forecasting System (WSFS; Bergström 1976, Vehviläinen et al. 2005) and the Integrated Nutrients in Catchments (INCA; Wade et al. 2002, Whitehead et al. 1998) models. The INCA model was calibrated against observed discharge at the outlet of the river. Inorganic nitrogen and suspended sediment time series were available also in the middle of the catchment.

The WSFS is a conceptual hydrological model, used in Finland for operational flood forecasting and for research purposes. The system is based on a watershed model, which has a HVB -hydrological model structure (Bergström 1976) and simulates the hydrological cycle using standard meteorological data.

The inputs of the model are precipitation and temperature and optionally potential evaporation. In climate change simulations the potential evaporation is calculated using an empirical equation from temperature, precipitation and time of year, which in turn is used to indicate the amount available of shortwave radiation (Vehviläinen and Huttunen 1997). Actual evapotranspiration is calculated from potential evaporation using simulated soil moisture. The simulated components of the hydrological cycle are snow accumulation and melt, soil moisture, evaporation, groundwater, runoff and discharges and water levels of major rivers and lakes.

The dynamic INCA models integrate hydrology and nutrient processes (Wade et al. 2002, Whitehead et al.,1998). The models are semi-distributed in that the land surface is not described in detail, but rather by land-use classes in sub-basins. Hydrologically effective rainfall (HER) is used to drive nutrients through the catchment system. HER is defined as that part of total incident precipitation that reaches stream channels as runoff and it is given as a daily input time series, which can be calculated by a hydrological model. Hydrology within the sub-catchments is modelled using a three-box approach, with reservoirs of water in a reactive soil zone and in the deeper groundwater zone and surface runoff.

In the INCA-N model sources of $\mathrm{N}$ include atmospheric deposition, fertilizers, leaching from the terrestrial environment and direct discharges. Terrestrial $\mathrm{N}$ fluxes are calculated in up to six user-defined land use classes. The mass balance equations for $\mathrm{NO}_{3}-\mathrm{N}$ and $\mathrm{NH}_{4}-\mathrm{N}$ in the soil and groundwater zones are solved simultaneously with the flow equations. The key $\mathrm{N}$ processes that are solved in the soil water zone are nitrification, denitrification, mineraliza- 
tion, immobilisation, $\mathrm{N}$ fixation and plant uptake of inorganic $\mathrm{N}$. No biochemical reactions are assumed to occur in the groundwater zone. In the river, the key $\mathrm{N}$ processes are nitrification and denitrification.

In the INCA-SED model, the main river channel is divided into a series of reaches and the land area that drains into each of these reaches is defined as a sub-catchment. The basic modelling unit of soil erosion processes is then a land use class in the sub-catchment. In addition, the model incorporates environmental data on hydrometeorology, land use, erodibility and catchment and channel morphology. Available sediment is generated on the catchment slopes by raindrop impact for each sub-catchment. Given sufficient direct runoff, this material is transported from the land to the in-stream phase of the model. Direct runoff can also further erode sediment from the soil surface. Suspended sediment concentration increases with stream power in the river. With decreasing stream power the sediment in suspension will settle and be deposited on the streambed.

The Lepsämänjoki river basin was divided into five sub basins based on predominant land use and crop, and location of discharge and water quality measurement stations. Three sub basins at the upper reaches $\left(34.4 \mathrm{~km}^{2}, 22.5\right.$ $\mathrm{km}^{2}$ and $26.2 \mathrm{~km}^{2}$ ) represent agricultural areas and two lower sub basins $\left(90 \mathrm{~km}^{2}\right.$ and $\left.36.7 \mathrm{~km}^{2}\right)$ more forested areas where field percentage was around 15\%. Six land uses were simulated: forest, fallow, grass, winter cereals, spring cereals and cabbage. Calibration of processes in different land use types was based on information about current agricultural practices (e.g. fertilizer and manure application, yield rates) of different crops (Mattila et al. 2007). These land uses were calibrated to produce same annual inorganic nitrogen and suspended sediment fluxes as measured in field trials (e.g. Turtola 1999, Ekholm et al. 2005, Salo and Turtola 2006, Puustinen et al. 2010). The sub catchments and land uses were the same for nitrogen and suspended sediment modelling.

The model was calibrated against daily measurements of discharge, and point measurements of suspended sediment, nitrate and ammonia nitrogen concentration at two national measurement stations. The focus of calibrating agricultural losses was on three upper reaches discharging to the water quality monitoring station in the middle of the Lepsämänjoki catchment where 3-16 samples were taken annually. A the outlet of the catchment there were more extensive water quality sampling of 17-30 samples taken annually. Further, in the uppermost reach there were four periods of automatic daily measurements of discharge and suspended sediments in 2008-2009.

The calibration period was 2003-2009, which provided the best continuous observation time series.

\section{Results and discussion Discharge and nutrient leaching for current land use}

Nash-Sutcliffe efficiency (used to assess the predictive power of the hydrological model, Nash and Sutcliffe 1970) was 0.699 for discharge at the outlet of the catchment. For nitrate, $R^{2}$ was 0.404 at the outlet and 0.392 in the middle of the catchment. The values of $R^{2}$ for suspended sediments were 0.552 and 0.199 . The baseline scenario and validation was run using the data for 1971-2000. The $R^{2}$ value was 0.495 for nitrate and for suspended sediments it was 0.184 in the middle of the catchment. Data from the outlet of the catchment were not available for this period.

Both INCA-N and INCA-SED models have been applied successfully to several catchments in Finland (Rankinen et al. 2009, Rankinen et al. 2010). INCA-N has been earlier shown to be sensitive especially to temperature dependency of different N processes and soil and river hydrology (Rankinen et al. 2006, Rankinen et al. 2013). Measured values of $\mathrm{NO}_{3}-\mathrm{N}$ concentrations were very well inside simulated 5 to $95 \%$ confidence limits. The only systematic model errors occured during low flow periods, when concentrations were either over- or underestimated. The effect of low flow periods on nutrient export from catchments was small. The simulation of suspended sediment concentration peaks in river by INCA-Sed proved to be sensitive to discharge velocity and in stream processes in clay areas (unpublished data). This is assumed not to influence the total suspended sediment export from the catchment. Thus we based our results on calculating changes in annual fluxes as average of 30 years.-

Mean annual discharge increases by 3\% for the period centred on 2025 and by 2055 it increases by $8 \%$. There is a gradual change towards higher discharges in winter, so that current peak due snow melting in April will disappear. Already in 2025 there will be a clear decrease in the snow-melt peak in April and an increase in discharge in autumn is evident (Fig. 3). On the other hand, no change is apparent in discharges during summer and early autumn. Snow cover does not totally disappear, but is lower and starts to melt earlier. Veijalainen et al. (2010) assessed climate change impacts on flooding on a national scale in Finland. They also reported a significant shift in 
the seasonality of runoff and floods, with increasing floods during autumn and winter, and diminishing floods in spring, especially in southern and central Finland.

Soil types in the Lepsämänjoki catchment are vulnerable to erosion. Thus suspended sediment load from the catchment would increase by $12 \%$ by the period $2040-2069$, but inorganic nitrogen load by about $6 \%$, if the field use remained the same as currently. By the period 2070-2099 inorganic nitrogen load would increase by $8 \%$ and suspended sediment load by $18 \%$. By the period 2011-2036 the increase would be only a few percentage points.

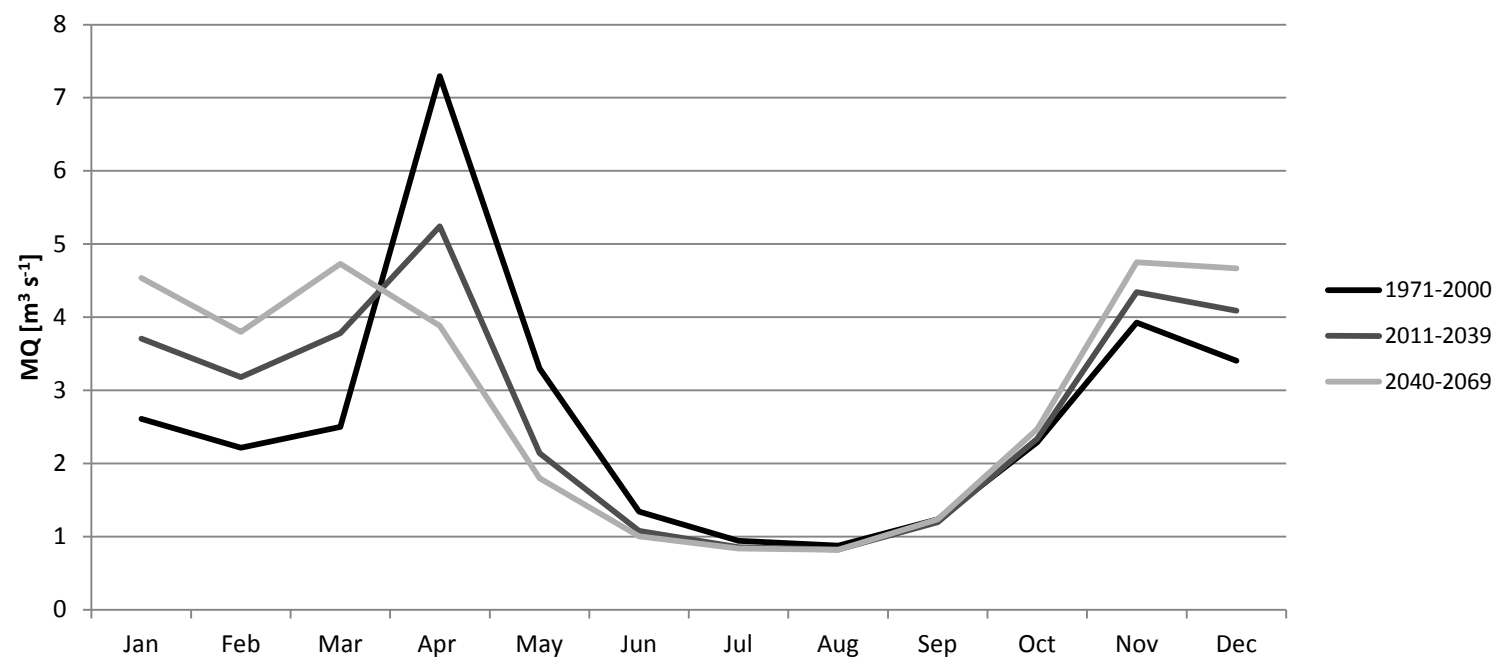

Fig. 3. Changes in mean monthly discharge into the Lepsämänjoki catchment in 30-year periods from present to 2055. Simulation results from Watershed Simulation and Forecasting System (WSFS, Bergström 1976).

\section{Future use of arable land}

In Storyline 1 (Fig. 4 protein crop production is strengthened according to future strategies (Rehustrategia 2010, Peltonen-Sainio and Niemi 2012). Therefore, oilseed rape (Brassica napus L.), turnip rape (B. rapa L.), faba bean (Vicia faba L.), field pea (Pisum sativum L.) and also lupins (Lupinus spp.) are expected to gain area, at the expense of spring-sown cereals by 2055. Spring wheat (Triticum aestivum L.), barley (Hordeum vulgare L.), oat (Avena sativa L.) and winter wheat remain in the crop selection by 2055. In storyline 1, small and impractically located and managed patches of fields become conservation fallows or naturally managed fields for enhancement of biological diversity. Pure stands of grain legumes are concentrated on parcels that are not next to waterways to attempt to lower risks for surface runoff and erosion-induced leaching of fixed nitrogen in autumn and winter (Geijersstam and Martensson 2006). On the other hand, oilseed rape and/or turnip rape are allocated to the largest parcels.

In Storyline 2 (Fig. 5), following the projections of Peltonen-Sainio et al. (2009a), winter cereals, winter wheat, rye (Secale cereale L.) and triticale ( $X$ Triticosecale Wittmack), are expected to gain in area, the latter being a novel crop, currently with only negligible areas under cultivation. Winter cereals are concentrated, when possible, in banked fields to avoid flooding and ice encasement, as is currently practised to avoid overwintering problems. Their expanded production is likely in the future, not only due to providing a means (soil crop cover) to reduce erosion and nutrient leaching risks, but also due to their higher yield potentials (Peltonen-Sainio et al. 2009a, Askegaard et al. 2011).

In Storyline 3 (Fig. 6) cereals are favoured by the farmers, and only negligible areas are devoted to spring oilseed rape. By the mid-century, to gain from high genetic yield potential of winter types compared to spring cereals, winter wheat, rye and triticale (Peltonen-Sainio et al. 2009a) are expected to be grown on $50 \%$ of the total area. Otherwise, farmers are considered to be very conservative and risk-averse regarding their crop selection (Peltonen-Sainio and Niemi 2012) and therefore, expected to favour cereal monocultures. 

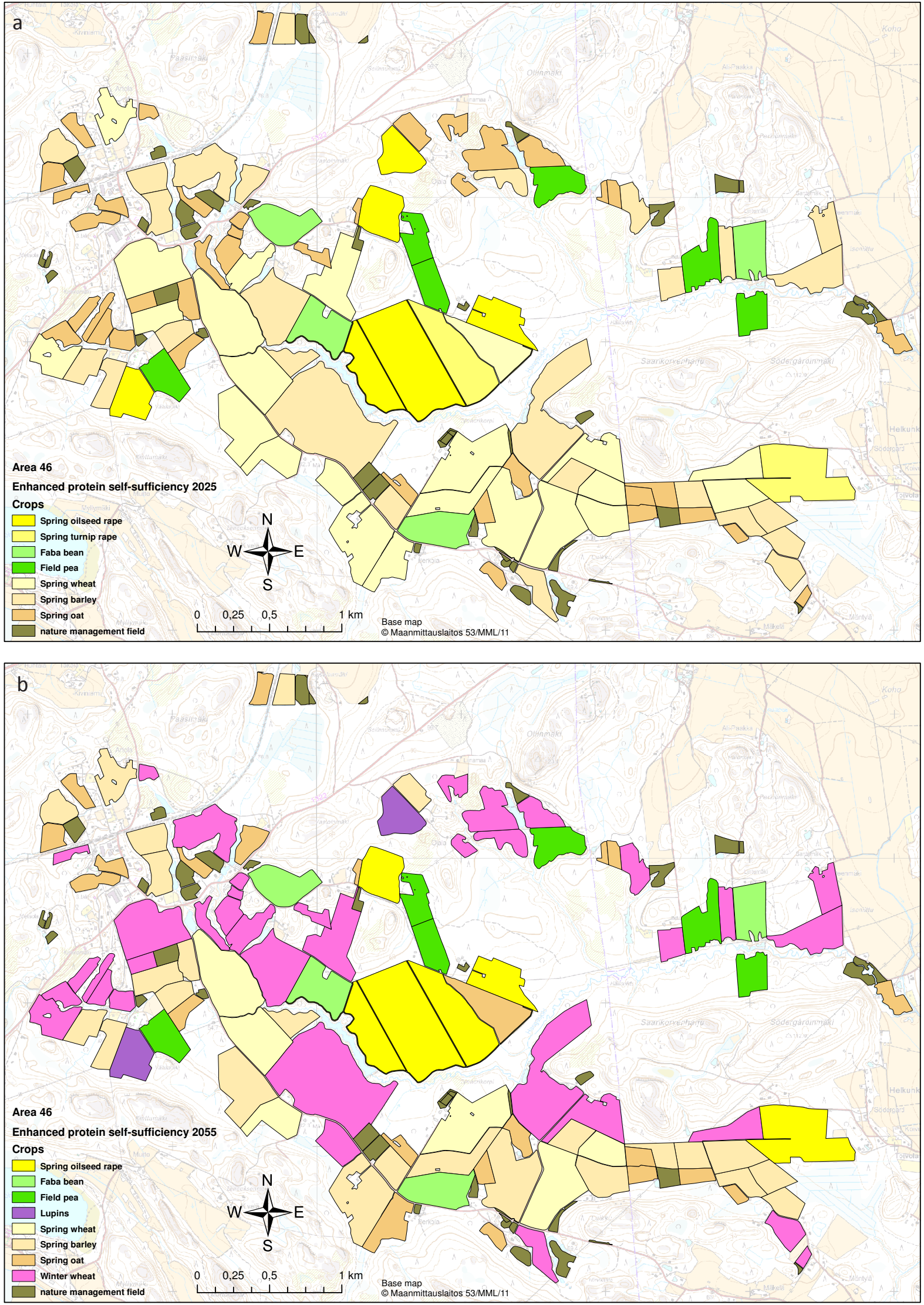

Fig. 4. Hypothetical field use in Storyline 1 ("protein crops") in the future changed climate in Lepsämäjoki catchment in Nurmijärvi, Finland in 2025 (a) and in 2055 (b) In this storyline, production of crops for protein food and feed is markedly enhanced, in order to improve crop-derived protein self-sufficiency. Estimations of field crops to be grown are based on climate change SRES scenario A2 (i.e., no marked mitigation achievements) of IPCC and 19 climatic models that were run for 30-year periods centred on either 2025 or 2055 (data provided by Finnish Meteorological Institute). For further details see Peltonen-Sainio et al. (2009a). 

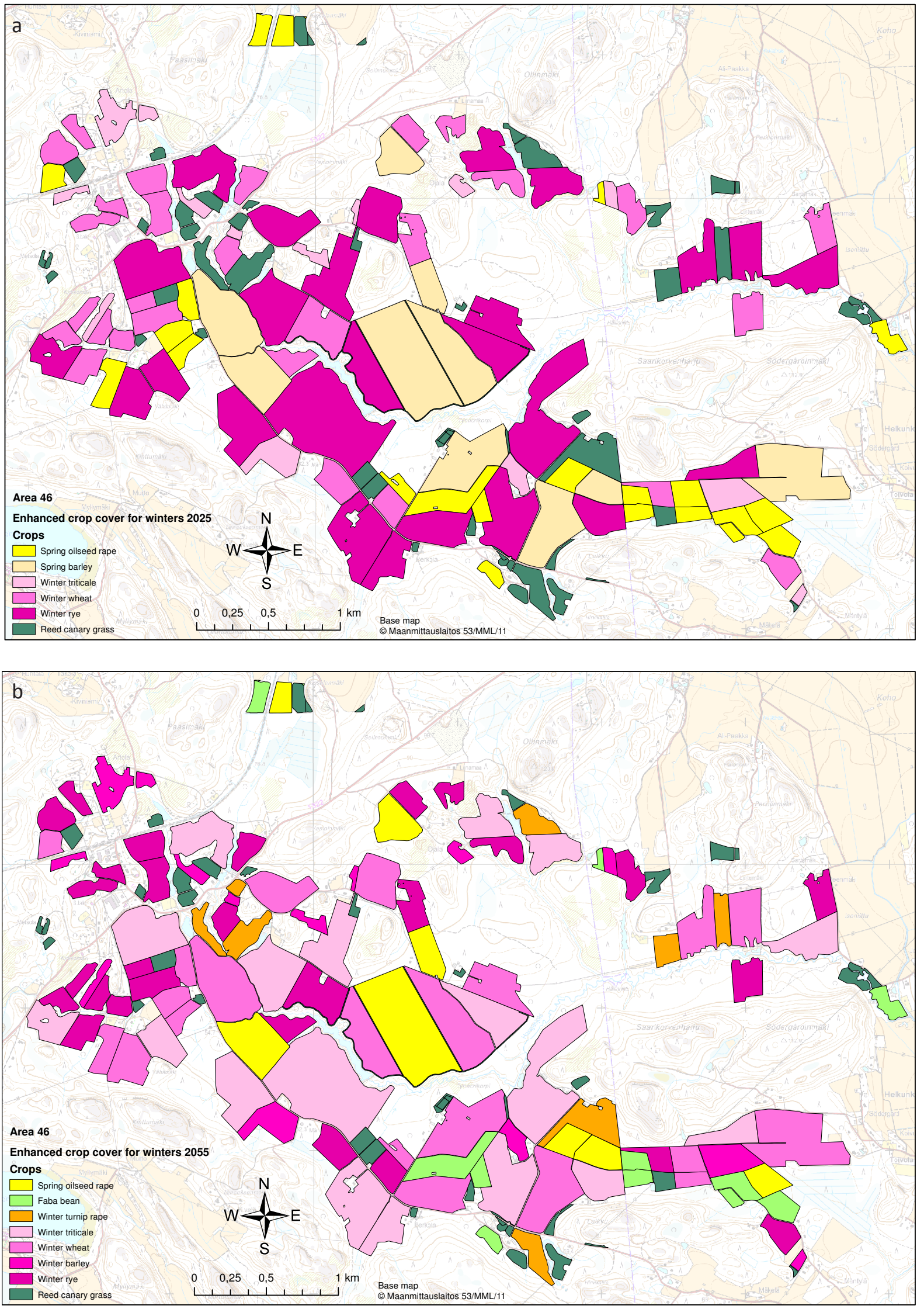

Fig. 5. Hypothetical field use in Storyline 2 ("winter cover") in the future changed climate in 2025 (a) and in 2055 (b). In this storyline, crop cover for winter is markedly enhanced in order to reduce erosion and nutrient leaching risks. For further details see caption of Fig. 4. 

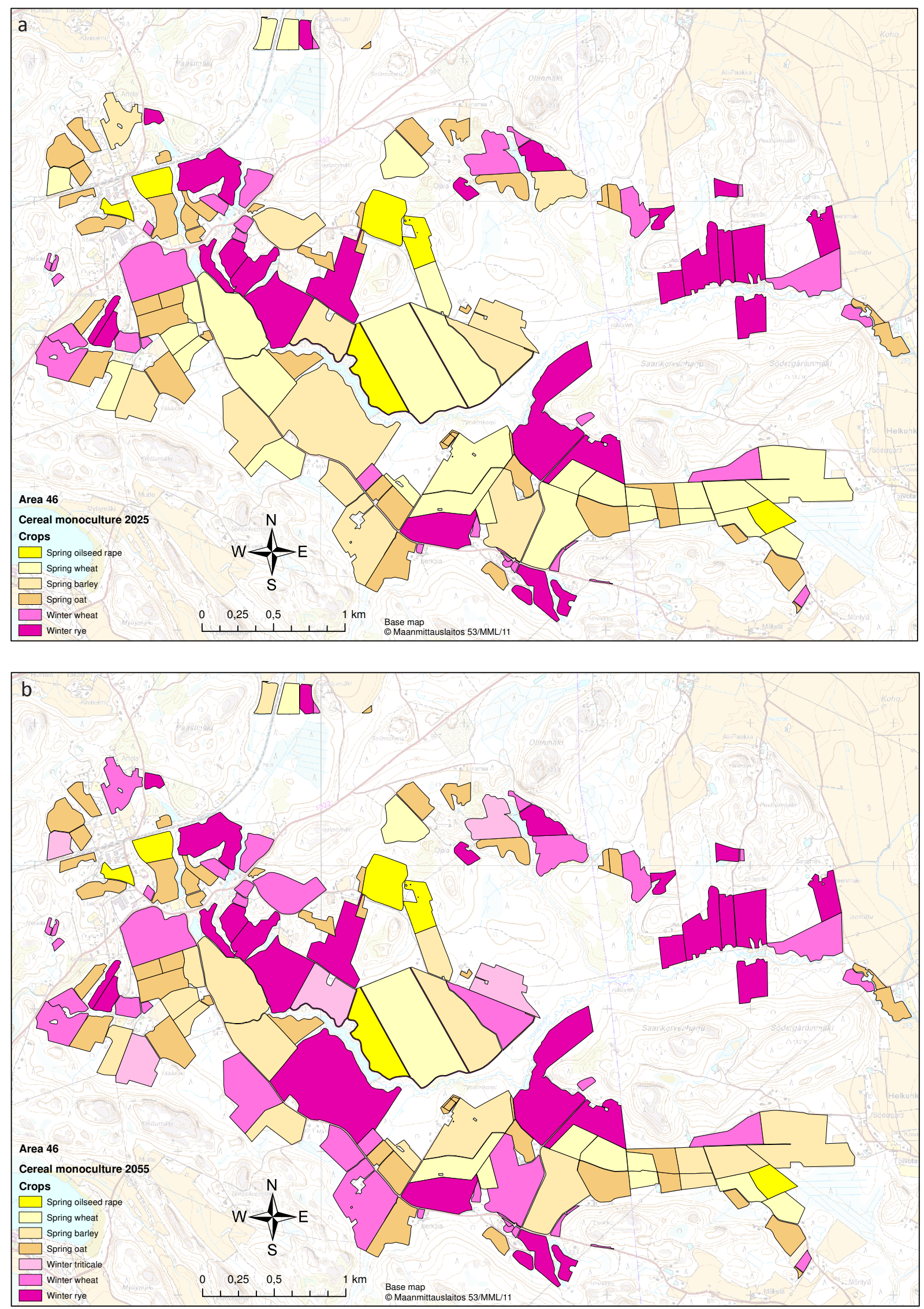

Fig. 6. Hypothetical field use in Storyline 3 ("monoculture") in the future changed climate in 2025 (a) and in 2055 (b). In this storyline, cereal monocultures continue to dominate. For further details see caption of Fig. 4 . 


\section{Nutrient leaching risk in future land use}

In the simulations of leaching risk in the future climate, and for each of the crop production storylines, the main focus is on 2025 and 2055. According to all the three storylines, the area of winter cereals will increase. This keeps soil covered and thus helps decrease erosion and suspended sediment transport. The effect is best seen in simulation results of suspended sediment loads (Fig. 7). In Storyline 2 ("winter cover") suspended sediment load slightly decreases in 2025 , but then starts to increase by $8 \%$ in 2055 , compared with the load during baseline conditions. Storyline 1 ("protein crops") will also provide a smaller increase in suspended sediment load than current vegetation cover (12\% increase by the period 2055), probably due to larger area of green fallow. In Storyline 3 ("monoculture") the increase in sediment load is higher than in Storylines 1 and 2.

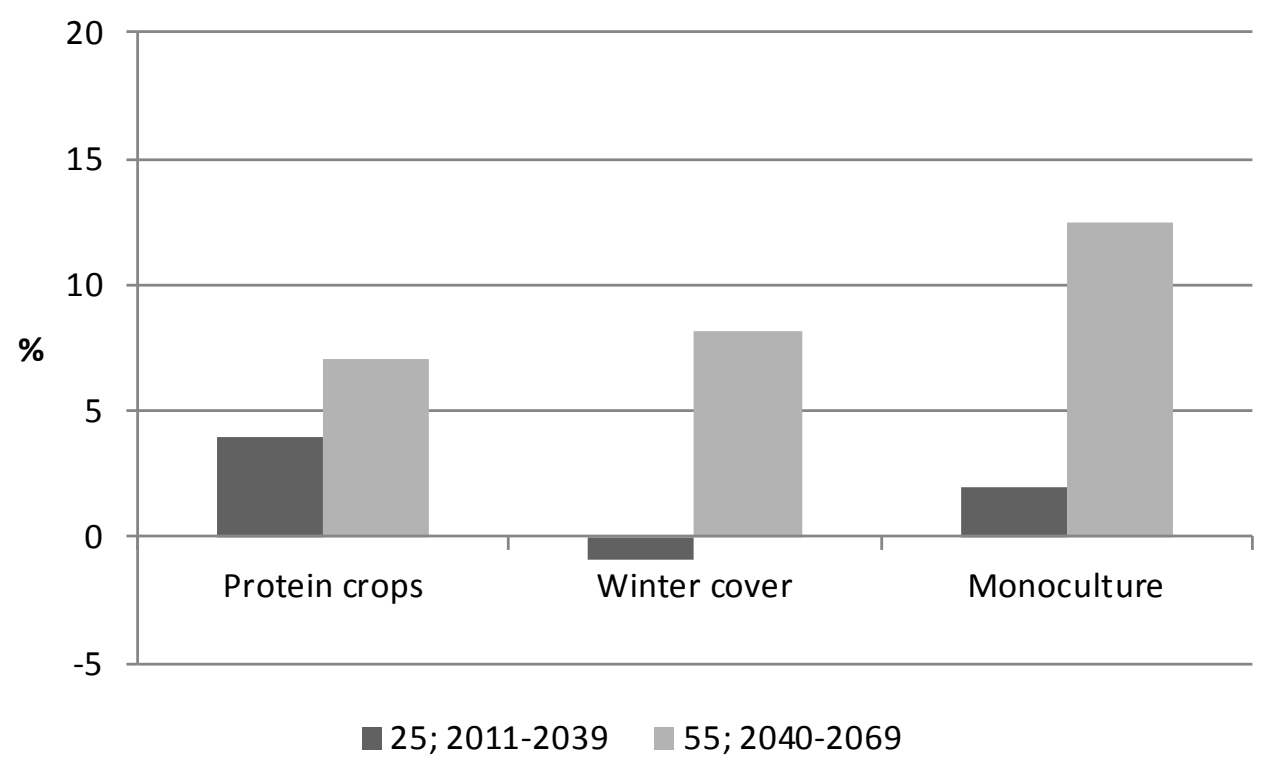

Fig. 7. Simulated changes in suspended sediment transport in the Lepsämänjoki study area, in three different storylines for future land use (see snapshot illustrations of land use in Figures 4, 5 and 7), compared with loads under baseline conditions.

In 2025 changes in inorganic N loading (Fig. 8) are relatively small for all the alternative uses of the farmland. In 2055 the changes will become more apparent. Surprisingly, the "monoculture" seems to provide the lowest inorganic nitrogen loading, so that the increase is only $3 \%$ by the 2055 period, and it compensates partly for the increase caused by current land use in a changing climate (6\% in 2055). On the other hand, in this storyline the average field balance of nitrogen decreases to $38 \mathrm{~kg} \mathrm{ha}^{-1}$ from the current value $42 \mathrm{~kg} \mathrm{ha} \mathrm{g}^{-1}$. In general, the fertilization level of spring cereals is lower than that of winter cereals, and we did not assume any changes in cropspecific fertilization volumes.

Increase in wintertime vegetation cover did not seem to compensate for increase in inorganic N leaching. The higher average plant uptake of winter cereals is met by a higher fertilization level than that of spring cereals, so that average field $\mathrm{N}$ balance remains $42 \mathrm{~kg} \mathrm{ha}^{-1}$. The highest leaching risk is associated with the "protein crops", which actually increase $\mathrm{N}$ loading more than climate change alone (Fig. 8). Even though average field $\mathrm{N}$ balance decreases to $33 \mathrm{~kg} \mathrm{ha}^{-1}$, the leaching from outside the growing season increases. Thus, it looks like leaching losses from cultivation based on mineral fertilizers only are smaller as the fertilization rates can be adjusted for crop uptake. On the other hand, nitrate concentrations do not approach $50 \mathrm{mg} \mathrm{l}^{-1}$, the boundary value of the Nitrate Directive. 


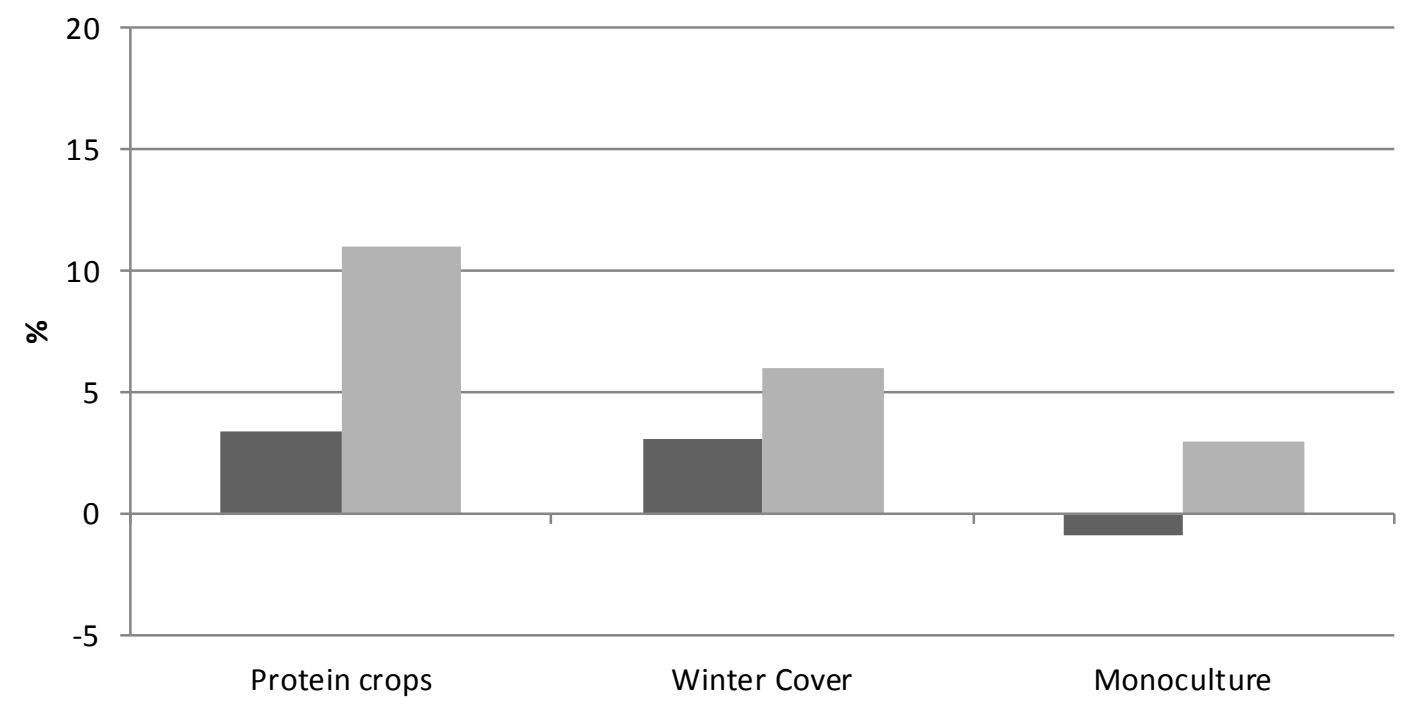

च25; 2011-2039 - 55; 2040-2069

Fig. 8. Changes in inorganic $\mathrm{N}$ loading in the Lepsämänjoki study area, in three different storylines for future land use (see snapshot illustrations of land use in Figures 4, 5 and 7), compared with loads in baseline conditions.

\section{Conclusions}

Climate change in Finland requires adaptation of agriculture. Opportunities may appear for introduction of crops new to the country or expanded cultivation of current minor or underutilized crops. Without adaptive changes in cropping systems, farming is especially vulnerable to the negative effects of climate change. Adaptation include consideration of crop plant choices, allocations and rotations.

In our simulated storylines of agricultural land use in changed climatic conditions in the Lepsämänjoki case study area, the expected increase in inorganic nitrogen and suspended sediment loading was projected to be moderate. The increase can partly be compensated for by changes in farmland use; more in the short term than in the longer term to the mid-century, when more effective water protection measures are needed. To reduce suspended sediment load in the changed climate, vegetation cover in winter is important. For inorganic nitrogen leaching, adjusting the $\mathrm{N}$ balance of crops seems to be more important than vegetation cover. Adaptation in cropping system and field use patterns is an efficient way to manage nutrient loading risks if it is feasible and/or enhanced by policy measures. Not all management options are synergistic in terms of their effects on nitrogen leaching and on suspended sediment loading. Therefore careful targeting is needed. Grasslands and leys were not included in any of the production scenarios.

\section{Acknowledgements}

We would like to thank coordinators of VACCIA Action 7 Kati Komulainen and Torsti Schulz, as well as the project coordinators and the many colleagues in the project. The work was partly financed by EU Life+ project Vulnerability assessment of ecosystem services for climate change impacts and adaptation (VACCIA) Action 7, Assessment of impacts and adaptation measures for agricultural production (EU LIFE+ programme, project LIFE07/ENV/ FIN/000141, 2009-2011). We thank Kirsti Jylhä for generating the localized climate change scenarios and Irmeli Ahtela for information on current water protection measures.

\section{References}

Alcamo, J. 2008. Environmental Futures: The Practice of Environmental Scenario Analysis. Amsterdam: Elsevier. 224 p.

Askegaard, M., Olesen, J.E., Rasmussen, I.A. \& Kristensen, K. 2011. Nitrate leaching from organic arable crop rotations is mostly determined by autumn field management. Agriculture, Ecosystems \& Environment 142: p.149-160. 
Bergström, S. 1976. Development and application of a conceptual runoff model for Scandinavian catchments. SMHI. Nr RH7. Norrköping. 134 p.

EEC 1991. Council Directive 91/676/EEC of 12 December 1991 concerning the protection of waters against pollution caused by nitrates from agricultural sources. Official Journal L 375 p. 1-8.

EEC 1992. Council Regulation (EEC) No 2078/92 of 30 June 1992 on agricultural production methods compatible with the requirements of the protection of the environment and the maintenance of the countryside. Official Journal of the European Communities No L215 p. 85-90.

Ekholm, P., Turtola, E., Grönroos, J., Seuri, P. \& Ylivainio, K. 2005. Phosphorus loss from different farming systems estimated from soil surface phosphorus balance. Agriculture, Ecosystems \& Environment 110: p.: 266-278.

Finnish Government 2006. Vesiensuojelun suuntaviivat vuoteen 2015, ValtioneuvostonperiaatepäätösIn Finnish.. Available on the Internet: http://valtioneuvosto.fi/ajankohtaista/tiedotteet/tiedote/fi.jsp?oid=175373. In Finnish.

Geijersstam, L.A. \& Martensson, A. 2006. Nitrogen fixation and residual effects of field pea intercropped with oats. Acta Agriculturae Scandinavica B-S P 56: p. 186-196.

Hakala, K., Hannukkala, A., Huusela-Veistola, E., Jalli, M. \& Peltonen-Sainio, P., 2011. Pests and diseases in a changing climate: a major challenge for Finnish crop production. Agriculture and Food Science. 20: p. 3-14.

Jylhä, K., Ruosteenoja, K., Räisänen, J., Venäläinen, A., Tuomenvirta, H., Ruokolainen, L., Saku, S. \& Seitola, T. 2009. Arvioita Suomen muuttuvasta ilmastosta sopeutumistutkimuksia varten. ACCLIM-hankkeen raportti 2009 RAPORTTEJA RAPPORTER REPORTS 2009:4. $114 \mathrm{p}$

Kallio, K., Huttunen, M., Vehviläinen, B., Ekholm, P. \& Laine, Y. 1997. Effect of climate change on nutrient transport from an agricultural basin. In: J. Roos (ed.). The Finnish Research Programme on Climate Change. Final report. Publications of the Academy of Finland 4/96.

Laapas, M., Jylhä, K. \& Tuomenvirta H. 2012. Climate change and future overwintering conditions of horticultural woody-plants in Finland. Boreal Environment Research. 17: p. 31-45.

Marttila, V., Granholm, H., Laanikari, J., Yrjölä, T., Aalto. A., Heikinheimo, P., Honkatukia, J., Järvinen, H., Liski, J., Merivirta, R. \& Paunio, M. 2005. Finland's national strategy for adaptation to climate change. Publications of the Ministry of Agriculture and Forestry 1/2005. 276 p. In Finnish with English abstract.

Mattila, P., Rankinen, K., Grönroos, J., Siimes, K., Karhu, E., Laitinen, P., Granlund, K., Ekholm \& P. Antikainen, R. 2007. Viljelytoimenpiteet ja vesistökuormitus ympäristötukitiloilla vuosina 2003-2005. Suomen ympäristö 40. In Finnish with English abstract.

MAVI 2011. Agri-environmental support scheme in Finland. Agency for Rural Affairs. Available on the Internet: http://www.mavi. fi/fi/index/viljelijatuet/oppaatjaohjeet/ymparistotuenjaluonnonhaittakorvauksensitoumusehdot/ymparistotuensitoumusehdot. html. Visited 2.12.2011. lin Finnish.

Ministry of Agriculture and Forestry 2011. Action plan for the adaptation to climate change of the Ministry of Agriculture and Forestry 2011-2015 - Security of supply, sustainable competitiveness and risk management. Memorandum, Ministry of Agriculture and Forestry. In:http://www.mmm.fi/attachments/mmm/julkaisut/muutjulkaisut/5yZhPxNpC/MMM_n_ilmastonmuutoksen_sopeutumisen_toimintaohjelma.pdf. In Finnish with English abstract.

Mäenpää, M. \& Tolonen, S. 2011. Kooste vesienhoitoalueiden vesienhoitosuunnitelmista vuoteen 2015. Suomen ympäristö 23. 122 p. In Finnish.

Nash, J.E., Sutcliffe, J.V. 1970. River flow forecasting through conceptional models. 1. A discussion of principles. Journal of Hydrology 10 p.: 282-290

Nakicenovic, N., Alcamo, J., Davis, G., de Vries, B., Fenhann, J., Gaffin, S., Gregory, K., Grübler, A., Jung, T.Y., Kram, T., La Rovere, E.L., Michaelis, L., Mori, S., Morita, T., Pepper, W., Pitcher, H., Price, L., Raihi, K., Roehrl, A., Rogner, H.-H., Sankovski, A., Schlesinger, M., Shukla, P., Smith, S., Swart, R., van Rooijen, S., Victor, N. \& Dadi, Z., 2000. Emissions Scenarios. A Special Report of Working Group III of the Intergovernmental Panel on Climate Change. Cambridge.Paikka?: Cambridge University Press. 599 p.

Olesen, J.E., Trnka, M., Kersebaum, K.C., Skjelvåg, A.O., Seguin, B., Peltonen-Sainio, P., Rossi, F., Kozyra, J. \& Micale, F. 2011. Impacts and adaptation of European crop production systems to climate change. European Journal of Agronomy. 34 :p. 96-112.

Peltonen-Sainio, P., Hakala, K., Jauhiainen, L., Ruosteenoja, K., 2009d. Comparing regional risks in producing turnip rape and oilseed rape - Impacts of climate change and breeding. Acta Agriculturae Scandinavica, B Soil and Plant Science 59: 129-138.

Peltonen-Sainio, P., Hannukkala, A., Huusela-Veistola, E., Voutila, L., Valaja, J., Niemi, J., Jauhiainen, L., Hakala, K., 2013. Potential and realities of enhancing rapeseed - and grain legume - based protein production in a northern climate. Journal of Agricultural Science 151: 303-321.

Peltonen-Sainio, P., Jauhiainen, L. \& Hakala, K. 2009b. Are there indications of climate change induced increases in variability of major field crops in the northernmost European conditions? Agricultural and Food Science 18: p. 206-226.

Peltonen-Sainio, P., Jauhiainen, L.\&, Hakala, K., 2011b. Crop responses to temperature and precipitation according to long-term multi-location trials at high-latitude conditions. Journal of Agricultural Science 149: p.: 49-62.

Peltonen-Sainio, P., Jauhiainen, L., Hakala, K. \&, Ojanen, H., 2009a. Climate change and prolongation of growing season: changes in regional potential for field crop production in Finland. Agricultural and Food ScienceAgr. Food Sci. 18: p.: 171-190.

Peltonen-Sainio, P., Jauhiainen, L. \&, Sadras, V.O., 2011a. Phenotypic plasticity of yield and agronomic traits in spring cereals and rapeseed at high latitudes. Field Crops Research 124: p.: 261-269.

Peltonen-Sainio, P. \&, Niemi, J., 2012. Protein crop production at the northern margin of farming: To boost, or not to boost, that is the question. Agricultural and Food ScienceAgr. Food Sci. 21: p.: 370-383. 
Peltonen-Sainio, P., Rajala, A., Känkänen, H. \& Hakala, K. 2009c. Improving farming systems in northern European conditions. In: Sadras, V.O. \& Calderini. D. (eds.). Crop Physiology: Applications for Genetic Improvement and Agronomy. Amsterdam, The Netherlands: Elsevier. p. 71-97.

Prime Minister's Office 2011. Prime Minister Jyrki Katainen's Government Programme. Helsinki.In Finnish.

Puustinen, M., Tattari, S., Koskiaho, J. \& Linjama, J. 2007. Influence of seasonal and annual hydrological variations on erosion and phosphorus transport from arable areas in Finland. Soil and Tillage Research. 93: p. 44-55.

Puustinen, M., Turtola, E., Kukkonen, M., Koskiaho, J., Linjama, J., Niinioja, R. \& Tattari, S. 2010 VIHMA-A tool for allocation of measures to control erosion and nutrient loading from Finnish agricultural catchments. Agriculture, Ecosystems \& Environment 138: p. 306-317.

Rankinen, K., Granlund, K., Futter, M.N., Butterfield, D., Wade, A., Skeffington, R., Arvola, L., Veijalainen, N., Huttunen, I. \& Lepistö, A. 2013 Controls on inorganic nitrogen leaching from Finnish catchments assessed using a sensitivity and uncertainty analysis of the INCA-N model. Boreal Environment. Research. 18: p. 373-386. In press.

Rankinen, K., Karvonen, T. \& Butterfield, D. 2006. An application of the GLUE methodology for estimating the parameters of the INCA-N model. Science of the Total Environment. 365: p.123-139.

Rankinen, K., Valpasvuo-Jaatinen, P., Karhunen, A., Kenttämies, K., Nenonen, S. \& Bärlund, I. 2009. Simulated nitrogen leaching patterns and adaptation to climate change in two Finnish river basins with contrasting land use and climatic conditions. Hydrology Research. 40: p. 177-186.

Rankinen, K., Thouvenot-Korppoo, M., Lazar, A., Lawrence, D.S.L., Butterfield, D. \& Lepistö, A. 2010. Application of catchment scale erosion and sediment delivery model INCA-Sed to four small study catchments in Finland. CATENA. 83: p. 64-75.

Rehustrategia 2010. Rehustrategiatyöryhmän raportti. Työryhmämuistio mmm 2010:9. 81 p. In Finnish..

Rekolainen, S., Ekholm, P., Ulén, B. \& Gustafson, A. 1997. Phosphorus losses from agriculture to surface waters in the Nordic countries. In: Tunney, H., Carton, O. T., Brookes, P. C. \& Johnston, A. E. (eds.). Phosphorus loss from soil to water. CAB International., p. 77-93.

Ruosteenoja, K., Räisänen, J. \& Pirinen, P. 2011. Projected changes in thermal seasons and the growing season in Finland. International Journal of Climatology. 31: p.1473-1487.

Räisänen, J.\& Eklund, J., 2011. $21^{\text {st }}$ Century changes in snow climate in Northern Europe: a high-resolution view from ENSEMBLES regional climate models. Climate Dynamics. DOI 10.1007/s00382-011-1076-3

Salo, T. \& Turtola, E. 2006. Nitrogen balance as an indicator of nitrogen leaching in Finland. Agriculture, Ecosystems \& Environment 113: p. 98-107.

Trnka, M., Olesen, J.E., Kersebaum, K.C., Skjelvåg, A.O., Eitzinger, J., Seguin, B., Peltonen-Sainio, P., Iglesias, A., Orlandini, S., Dubrovský, M., Hlavinka, P., Balek, J., Eckersten, H., Cloppet, E., Calanca, P., Rötter, R., Gobin, A., Vucetic V., Nejedlik, P., Kumar, S., Lalic, B., Mestre, A., Rossi, F., Kozyra, J., Semerádová, D. \& Zalud, Z. 2011. Agroclimatic conditions in Europe under climate change. Global Change Biology 17: p. 2298-2318.

Turtola, E. 1999. Phosphorus in surface runoff and drainage water affected by cultivation practices. Agricultural Research Centre of Finland.

Veijalainen, N., Lotsari, E., Alho, P., Vehviläinen, B. \& Käyhkö, J. 2010. National scale assessment of climate change impacts on flooding in Finland. Journal of Hydrology 391: p. 333-350.

Vehviläinen, B. \& Huttunen, M. 1997 Climate change and water resources in Finland. Boreal Environmet Research 2: p. 3-18.

Vehviläinen, B., Huttunen, M. \& Huttunen, I. 2005. Hydrological forecasting and real time monitoring in Finland: the watershed simulation and forecasting system (WSFS). In: Innovation, Advances and Implementation of Flood Forecasting Technology, Conference Papers, Troms $\varnothing$, Norway, 17-19 October 2005.

Wade, A. Durand, P., Beaujoan, V., Wessels, W., Raat, K., Whitehead, P. G., Butterfield, D., Rankinen K. \& Lepistö A. 2002. Towards a generic nitrogen model of European ecosystems: New model structure and equations. Hydrology and Earth System Sciences 6: p. 559-582.

WFD 2000. Water Framework Directive. Directive 2000/60/EC of the European Parliament and the Council of 23 October 2000 establishing a framework for community action in the field of water policy. Official Journal of European Community, L 327 p. 1-73.

Whitehead, P.G., Wilson, E.J. \& Butterfield, D. 1998. A semi-distributed Integrated Nitrogen model for multiple source assessment in Catchments (INCA): Part I-model structure and process equations. Science of the Total Environment. 210/211: p. 547-558. 